of dominance and human emancipation, a perspective no less alien to the trade union movement. But that is another story.

\title{
Michel Pigenet
}

Centre d'Histoire sociale des mondes contemporains (UMR 8058)

Université Paris I Panthéon-Sorbonne 9 rue Malher 75004 Paris, France

E-mail: Michel.Pigenet@univ-paris r.fr doi:10.1017/S0020859019000622

De Graaf, Jan. Socialism across the Iron Curtain. Socialist Parties in East and West and the Reconstruction of Europe after 1945. [New Studies in European History.] Cambridge University Press, Cambridge 20I9. xii, 320 pp. £75.00. (E-book: \$84.00.)

Woloch, Isser. The Postwar Moment. Progressive Forces in Britain, France, and the United States after World War II. Yale University Press, New Haven (CT) [etc.] 2019. xxii, 5 is pp. Ill. \$40.00.

The historian Geoff Eley has identified post-war periods as moments of exceptional potential. The disruptions attendant on major war create opportunities for recasting the dominant order at home and abroad as the forces underpinning the status quo emerge weakened and as actors become capable of imagining futures hitherto inconceivable. For Eley, such moments are also short-lived: older habits, familiar frameworks, and vested interests quickly combine to close windows of opportunity. ${ }^{\text {I }}$

Eley's model is pertinent to the two books under review, for both deal with the years after World War II. The two books have other things in common: both examine political forces on the left, socialist (or social democratic) parties for Jan de Graaf and "progressives" for Isser Woloch; both seek to explain why some countries witnessed more progressive reforms than others; and, last but not least, both adopt an explicitly comparative approach.

Of the two books, De Graaf's is the most rigorously comparative, with each chapter carefully examining the positions of the Czech, French, Italian, and Polish socialist (noncommunist) parties. The results, hammered home repeatedly, are striking: the Polish and Italian parties and the Czech and French parties had more in common with each other than an East-West conceptual map would lead one to expect. In emphasizing these two groupings, De Graaf seeks to challenge several historiographical tendencies. One is the Western centrism of most histories of European socialism, which, he rightly notes, all too often neglect Eastern Europe. Another tendency is to draw sharp lines between the socialist parties in Soviet-dominated Eastern Europe after I945 from those in Western, Northern, and Southern Europe. A final tendency - and perhaps the most relevant in terms of Eley's model - is to view European socialism as irredeemably reformist with socialist parties embracing the American-led Western alliance abroad and versions of market capitalism at home.

I. Geoff Eley, "Europe after 1945”, History Workshop Journal, 65 (2008), pp. 207-208. 
De Graaf's comparative method is effective. By the end of the book, one is largely convinced that European socialist parties did not form two separate Eastern and Western blocs in the immediate years after 1945. On several key issues (forms of local popular democracy, attitudes towards strikes and towards the urban industrial working class more generally, cooperation with communists, confidence in parliamentary democracy, the legitimacy of violence to gain political power, and relations with socialist parties abroad) the fault lines ran across EastWest divisions. More precisely, the French and Czech parties emerge as archetypes of post-war socialist reformism - viscerally anti-communist, deeply suspicious of grass-roots activity, reluctant to identify as working-class parties, prepared to subordinate the interests of urban workers to larger "national" interests, profoundly committed to parliamentary politics, and all too willing to view productivism as an end rather than a means. The Polish and Italian parties, by contrast, appear as revolutionary organizations, identifying with the perceived interests of urban workers, determined to encourage grass-roots efforts, and fully prepared to work with communists to challenge the political, economic, and social order. Contrary to the familiar argument that European socialism's reformist course was set in the post-I9I7 period in response to war and Bolshevik revolution, De Graaf insists that the years after 1945 saw a struggle across Europe to define socialism as a political project. The outcome of this struggle, he adds, was not pre-determined but depended on unfolding political dynamics in each country. No less importantly, De Graaf traces the roots of the differences between socialist parties to the interwar period. Parliamentary democracy withered and died in Poland and Italy, helping to radicalize socialists in both countries. In France and Czechoslovakia, by comparison, a vibrant democracy thrived for much of the interwar period, rendering French and Czech socialists suspicious of more radical and popular forms of politics.

Woloch's comparative method is less structured than De Graaf's, comprising three separate case studies: Britain, France, and the United States. During the interwar period, progressive forces centred on Labour and the TUC in Britain, the Socialist Party (SFIO) in France, and the New Deal administration in the United States. At times, Woloch appears to favour a corporatist approach in which the fate of progressive reforms rested on the shifting balance of power in each country between trade unions and their political allies, the government, and employer groups and their political allies. But if so, the argument is never made explicitly, and a corporatist approach arguably works better for some cases than others.

In many ways, the British case is the most straightforward one. As part of Churchill's wartime coalition, Labour focused on winning the war but was prodded into thinking about the post-war period by political developments largely beyond its control, most notably the publication of the Beveridge Plan. Having won a decisive majority in the spring 1945 general elections, Labour was in a commanding position to implement its own version of the Beveridge Plan, summed up in the electoral platform, Let Us Face the Future, which promised large-scale collective provision for housing, social insurance, healthcare and education, as well as the nationalization of key industries. Despite resistance from vested interests and a precarious financial situation, the Labour government forged ahead, profoundly revising Britain's social-economic landscape. In France, no single political party possessed a parliamentary majority. Instead, in the immediate post-war years, the socialists allied with the communists (PCF) and the democratic Catholics, grouped together in a new party (MRP), in a shared commitment to the political programme of the united wartime resistance that called for punishment of collaborators and extensive yet vague reforms to create "a veritable economic and social democracy" (p. 8I). No less importantly, the state would be accorded a leading role in the economy in what came to be known as dirigisme. The PCF had initially offered to form an exclusive coalition with the SFIO but the latter insisted 
on including the MRP. Woloch emphasizes the progressive nature of the MRP, though the party is perhaps best viewed as a fragile amalgam of competing political currents. In any event, successive tripartite governments between 1945 and 1947 lacked the single purposefulness of the Labour government in Britain: while implementing some reforms, most notably the expansion of social security, they proved less successful in education, housing, and healthcare. With the ejection of communist ministers from the government in May 1947, tripartisme gave way to Third Force governments as the SFIO and the MRP combined to block anti-Republican forces - the PCF on the left and the Gaullists on the right. In a context of Republican defence, leavened by a surging anti-communism, the time for far-reaching progressive reforms had passed.

The American case is perhaps the most difficult to assess. The New Deal's momentum for reform had stalled even before the American entry into the war, and Roosevelt's priority on winning the war further weakened its residual reformist potential. Early in the post-war period, the Truman Administration suffered major defeats as Congress gutted the ambitious Employment Act, a charter for post-war economic planning, and as the National Association of Manufacturers, a principal business lobby group, mobilized considerable resources to kill the Office of Price Administration, a wartime agency whose continued existence embodied the belief that wartime economic controls were needed to avoid the disruptions of a brusque return to free-market capitalism. Woloch argues against the notion that the United States "moved in an opposite direction" from Britain and France in terms of progressive reforms, pointing, for example, to the Truman administration's measures concerning race relations, most notably the decision in 1948 to desegregate the American armed forces (p. 4 I 5 ). Yet, such measures, however welcome, seem paltry in the face of persistent Congressional opposition to reform, reinforced by sweeping Republican victories in the 1946 mid-term elections. The Senate, in Woloch's telling phrase, "remained the graveyard for all civil rights legislation" (p. 386). No less regrettably, the Truman administration between I 949 and I952 lost the "big battle" for universal healthcare, a victim of the American Medical Association's mendacious lobbying, while also failing to repeal anti-trade union legislation (p. 4I 7). All told, the post-war American experience does seem to stand out, especially when compared to the British one.

Examining these two books together prompts several comments. The first concerns comparative history. De Graaf uses this method to better effect than Woloch in the service of a distinct argument: that the history of European socialism in the immediate post-war years cannot be organized along East-West lines. Woloch's overall argument is less clear. Much of De Graaf's thesis, however, rests on the case of Italian socialism, which was arguably an outlier. None of the other Western European parties were similar. If De Graaf had chosen any other "Western" party (British, German, Dutch, Belgian, a Scandinavian one) to compare to the SFIO, the sharp contrasts he sketches would fade. Generally speaking, Western European socialism by i945 was profoundly reformist, though this does not necessarily mean it was not progressive - if progressive is defined in terms of collective provision and restraints on the working of the market economy. Definitions of progressive, in turn, raise the question of post-war possibilities. As historians, both De Graaf and Woloch emphasize contingency: while tracing socialist or progressive impulses back to the interwar period, they both maintain that the particular post-war political constellations in countries under study go far in explaining the extent of socialist and progressive politics. It is always hard to argue against contingency but perhaps it is worth highlighting structural factors, particularly the differences in post-war political regimes. Britain's parliamentary system, which endowed majority governments with dominating executive authority, proved to be an apt instrument in Labour's hands. Nothing similar existed in France, whose Fourth Republic, 
much like its predecessor, combined a fractured legislature with a weak executive; or in the United States, which opposed a powerful and often fractured legislative branch with an executive whose authority swelled in times of war (or quasi-war such as the Cold War) but seemed to shrink in peacetime.

Another and related comment concerns time frames. Eley, to recall, identified post-wars as moments of unique possibility. This appears to be the case for Britain: the wartime experience provided the necessary conditions not only for Labour's decisive electoral victory in 1945, but also for the Labour government's far-reaching programme. But Eley's argument applies less well to the French and American cases. Woloch mentions as an intriguing possibility an SFIO-PCF coalition in 1945, though it is questionable whether the two parties could have agreed on a more ambitious reform agenda than the one that emerged from tripartisme. But this counter-factual aside, the dynamics of post-war French politics, like those of American politics, placed very real limits on change. Once again, this points to the importance of political regimes. Ironically, the experience of defeat and occupation did not fundamentally alter France's parliamentary democracy: in its functioning, the Fourth Republic resembled the Third Republic and the latter, as the political scientists Stanley Hoffmann famously remarked, possessed better brakes than it did an engine. To be sure, Britain's political regime also remained unchanged but the Westminster model could become, as already mentioned, a remarkably effective instrument for reform.

A final comment on time frames: if the nature of political regimes is as important a factor as post-war periods in explaining change, there is something to be said for a longer-term view. Here, there are at least two perspectives. One is the decisive effects of failure. If there was a historical moment for the introduction of universal healthcare in the United States, it was during the Truman administration. Afterwards, the opposing forces were too strong during the twentieth century. But another perspective is to approach reform as an ongoing project and not the product of one particular moment. In the French case, the healthcare system that emerged after the war was organized along professional lines, with different professions possessing their own insurance accounts (caisses), an arrangement that undermined the principle of universality. Yet, in subsequent decades, the French system would undergo further and extensive reform in a universalist direction as the configuration of interests altered. However significant they may be, post-war periods are not the only moments when farreaching change is possible.

\section{Talbot Imlay}

Département des sciences historiques, Université Laval Pavillon Charles-De Koninck, I030, avenue des Sciences humaines, Bureau 3237

Québec Gi V oA6, Canada

E-mail: Talbot.Imlay@hst.ulaval.ca doi:I0.1017/S0020859019000634

Higbie, Tobias. Labor's Mind. A History of Working-Class Intellectual Life. University of Illinois Press, Urbana (IL) 2019. 208 pp. \$99.00. (Paper: \$2 5.00.)

Tobias Higbie's new social history of the working-class mind opens with an evocative anecdote that illustrates both the productive insights and important challenges of his project. 